CATALLAXY

Volume 3 Issue 2 December 2018

e-ISSN 2544-090X

¿ www.catallaxy.pl

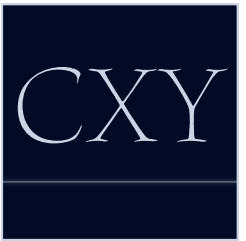

Oryginalny artykut naukowy

otrzymano: 07.05.2018 / zaakceptowano: 25.06.2018 / opublikowano online: 30.06 .2018

Skorupka, A. (2018). Efekt wypychania prywatnych transferów przez publiczny system emerytalny. Catallaxy, 3(2): 103-110. doi:10.24136/cxy.2018.005.

\title{
Efekt wypychania prywatnych transferów przez publiczny system emerytalny
}

\author{
AGATA SKORUPKA \\ Szkoła Gtówna Handlowa w Warszawie, al. Niepodległości 162, 02-554 Warszawa, Polska \\ వagata.skorupka@gmail.com \\ (D) orcid.org/0000-0003-4487-8758
}

\begin{abstract}
Abstrakt
Motywacja: Według Banku Światowego, wprowadzenie emerytur wypiera aż od 20\% do $91 \%$ prywatnych transferów. Efekt wypychania jest największy dla najuboższych gospodarstw domowych, czyli tych, które powinny być głównymi beneficjentami publicznego systemu emerytalnego. Wedle poglądów prezentowanych $w$ literaturze, poddaje to $w$ wątpliwość zasadność wprowadzenia powszechnego systemu emerytalnego.

Cel: Celem artykułu jest próba odpowiedzi na pytanie, czy wprowadzenie obowiązkowego systemu emerytalnego skutkuje wypchnięciem prywatnych transferów, skierowanych do osób starszych, a także, w przypadku odpowiedzi twierdzącej, ewentualne określenie skali tego zjawiska. Pozwoli to ocenić celowość wprowadzenia powszechnego systemu emerytalnego w państwach rozwijających się.

Materiały i metody: Dokonano krytycznego przeglądu badań empirycznych, zaprezentowanych w literaturze, a następnie zweryfikowano je przy pomocy zmodyfikowanego modelu OLG (overlapping generations). Symulacji dokonano w programie Dynare/Octave.

Wyniki: Dowiedziono, że nawet jeśli efekt wypychania istnieje w skrajnej formie, nie należy na tej podstawie wyciągać wniosków o sprawności funkcjonowania systemu emerytalnego. Co więcej, nawet w takim przypadku, jego wprowadzenie jest opłacalne - zwiększa łączną konsumpcję oraz społeczny dobrobyt.

Stowa kluczowe: system emerytalny; srebrna gospodarka; OLG

JEL: J11; J14;J18
\end{abstract}

\section{Wprowadzenie}

Celem artykułu jest próba odpowiedzi na pytanie, czy wprowadzenie obowiązkowego systemu emerytalnego skutkuje wypchnięciem prywatnych transferów, skierowanych do osób starszych, a także, w przypadku odpowiedzi twierdzącej, ewentualne określenie skali tego zjawiska. Skoro intencją wprowadzenia powszechnego systemu emerytalnego jest zwiększenie konsumpcji starszych ludzi, to istnienie odpowiednio dużego efektu wypychania może w całości zniwelować ten cel (konsumpcja jednocześnie obniża się wskutek spadku wsparcia finansowego ze strony rodziny). Poddaje to w wątpliwość samą zasadność wprowadzenia powszechnego systemu emerytalnego. Przykładowo, według Banku Światowego (World Bank, 2001, ss. 147-159), wprowadzenie emerytur wypycha aż od $20 \%$ 
do $91 \%$ prywatnych transferów ${ }^{1}$. Jednocześnie efekt wypychania jest największy dla najuboższych gospodarstw domowych, czyli tych, którzy powinni być głównymi beneficjentami publicznego systemu emerytalnego ${ }^{2}$.

Artykuł podzielono na pięć sekcji. W sekcji 2. dokonano krytycznego przeglądu wyników badań empirycznych. W sekcji 3 . zaproponowano nowe podejście do problemu przy pomocy modelu OLG (overlapping generations). W sekcji 4. zaprezentowano wyniki przeprowadzonej analizy. Sekcja 5. stanowi podsumowanie otrzymanych wniosków.

\section{Przegląd literatury}

Spór o to, czy efekt wypychania rzeczywiście istnieje, ma swoje korzenie $\mathrm{w}$ pytaniu o motywy transferów pieniężnych wewnątrz rodziny ${ }^{3}$. Można wyróżnić dwa główne podejścia, mające oparcie $w$ modelach mikroekonomicznych: altruistycznym oraz wymiany. Według pierwszego, potomkowie wspierają osoby starsze, gdyż cechują się altruizmem, tzn. czynią to "z dobrego serca” (Barro, 1974, ss. 1095-1117; Becker, 1974, ss. 1063-1093). Drugie natomiast zakłada istnienie nieformalnego kontraktu: rodzice finansują młode potomstwo (m.in. inwestują $\mathrm{w}$ ich edukację), w zamian za to dzieci opłacają konsumpcje rodziców w okresie, gdy nie są oni już zdolni do pracy (Bernheim i in., 1985, ss. 1045-1076; Cox, 1987, ss. 508-546). Prywatne transfery, otrzymywane w okresie starości są w tym ujęciu wypełnianiem zawartego wcześniej zobowiązania - finansowanie konsumpcji dziecka podczas jego młodości traktowane jest jako

Ramy te wyznaczono poprzez zebranie wyników z poszczególnych badań (niejednokrotnie o bardzo odmiennych metodologiach), a nie w oparciu o jedno całościowe badanie. Poddaje to w wątpliwość sens posługiwania się tym szacunkiem.

W związku z czym w literaturze są wysuwane postulaty publicznej kompensacji gospodarstwom domowym ubytku w prywatnych transferach (Cox i in., 2004, ss. 2193-2219).

Na wyższym poziomie ogólności można stwierdzić, że powodem dokonywania transferów pieniężnych wewnątrz rodziny jest niedoskonałość rynków kapitałowych. W związku z tym, skoro nie mogą one służyć wygładzaniu konsumpcji w cyklu życia, rolę tę zaczyna pełnić rodzina i wypłacane przez nią transfery. D. Cox i in. (1997, ss. 57-80), przedstawiają dowód na tę tezę, pokazując, że przypływ transferów od członków rodziny następuje w szczególności w okresie dziecięcym oraz starczym. pożyczka, którą spłaci rodzicom finansując ich starość.

Według modelu altruistycznego, wzrost dochodów własnych adresata transferu (dalej też jako: dochody przedtransferowe, czyli te, jakimi dysponuje przed otrzymaniem przepływu), skutkować będzie redukcją otrzymywanego transferu (zmniejsza się krańcowa użyteczność osoby transferującej $z$ takiego przesunięcia konsumpcji). Prowadzi to do wniosku, że w takim ujęciu efekt wypychania zawsze wystąpi $i^{4}$. Zgodnie $z$ modelem wymiany, istnienie efektu wypychania nie jest przesądzone. Dopuszczana jest sytuacja, w której zwiększenie dochodu przedtransferowego spowoduje, że transfery zamiast zmaleć, wzrosną. Za tę niejednoznaczność odpowiedzialne są dwa efekty działające w przeciwnych kierunkach. Po pierwsze, wzrost dochodów przedtransferowych sprawia, że popyt podmiotu na fundusze pożyczkowe $z$ mniejsza się, bo jest on $\mathrm{w}$ stanie sfinansować większą część konsumpcji samodzielnie (skutkuje to spadkiem transferów). $Z$ drugiej strony, wzrasta wartość groźby, tzn. użyteczność, którą podmiot może otrzymać sam, bez zawierania kontraktu $z$ drugim $^{5}$. Oznacza to, że będzie on mógł pożyczać na lepszych warunkach (rezultatem będzie wzrost transferów). Ostateczny wynik zależny jest od tego, który z obu efektów będzie silniejszy.

Podsumowując dotychczasowe rozważania można stwierdzić, że efekt wypycha-

${ }^{4}$ Koncepcja ta może być poddana krytyce jako nadmiernie uproszczona. W ocenie opłacalności dokonania transferu, jednostki modelowo kierują się początkowym dochodem beneficjenta w ujęciu absolutnym. Życie społeczne pokazuje natomiast, że członkowie rodziny dążą raczej do zbliżenia poziomu konsumpcji między sobą. W związku z tym, w rzeczywistym świecie agenci mogą przyjmować swoje dochody jako punkt odniesienia w ocenie, czy zasoby początkowe beneficjenta transferu są wystarczająco niskie. Przykładowo, jeśli dochody rodzica w wieku poprodukcyjnym wzrosna, to zgodnie z modelem, finansujący jego konsumpcję potomek powinien zmniejszyć transfer dokonywany na jego rzecz. Jednak jeśli w tym czasie dochody potomka wzrosną silniej niż dochody rodzica, to może być tak, że potomek będzie postrzegat sytuację materialną rodzica gorzej niż wcześniej (porównuje ją ze swoja). W takim przypadku transfer także wzrośnie. Wtedy efekt wypychania nie wystąpitby. Model nie przewiduje takiej możliwości.

Rozwiązanie modelu wymiany odbywa się według schematu arbitrażowego Nasha, tzn. przez znalezienie wartości groźby oraz maksymalizację iloczynu odchyleń użyteczności obu podmiotów od ich wartości groźby. 
nia z całą pewnością wystąpi, jeżeli jednostki dokonujące transferów działają czysto altruistycznie, natomiast nie musi mieć miejsca, gdy postępują $\mathrm{w}$ oparciu o model wymiany. Problem istnienia efektu wypychania sprowadza się tym samym do oszacowania znaku pochodnej transferów względem dochodu przedtransferowego. Ujęcie takie byłoby jednak niepełne. Może być przecież tak, że wartość poszczególnych transferów wzrośnie, ale zmaleje liczba otrzymujących je gospodarstw domowych. W związku z tym, należy także obliczyć zmianę prawdopodobieństwa otrzymania transferu po wzroście dochodu (dokonuje się to najczęściej przy pomocy modelu probitowego).

D. Cox i in. (2004, ss. 2193-2219), zwrócili uwagę na fakt, że pochodna transferów względem dochodu przedtransferowego może być nieliniowa, tj. motywy dokonywania transferów mogą być różne w zależności od osiąganego dochodu. Ich zdaniem, nieuwzględnienie zależności nieliniowych było czynnikiem, który sprawiał, że do tej pory efekt wypychania był niedoszacowany, bądź nieistotny statystycznie. Według nich, biedniejsze gospodarstwa domowe dokonywały przepływów pieniężnych wewnątrz rodziny, zgodnie $z$ modelem altruistycznym (a co za tym idzie, są bardziej podatne na negatywne konsekwencje efektu wypychania), natomiast bogatsze $-z$ modelem wymiany.

W celu oceny zasadności obaw związanych $z$ efektem wypychania, przydatnym będzie przegląd wyników badań empirycznych, poświęconych tej kwestii. D. Kaufmann i D. Lindauer (1986, ss. 337-350), przeprowadzili badanie w Salwadorze, gdzie stwierdzono efekt wypychania na poziomie $55 \%$ dla gospodarstw domowych o dochodzie znajdującym się poniżej linii ubóstwa oraz brak efektu wypychania dla pozostałych. Wadą badania jest mała próba (500 gospodarstw domowych) i fakt, że pochodziła ona $z$ jednego miasta (Santa Ana). Wydaje się zatem, że uogólnienia na podstawie przytoczonych wyników mogą być niezasadne (mieszkańcy miasta moga choćby cechować się specyficznymi zwyczajami). Autorzy badania jako pierwsi zastosowali nieliniowe metody estymacji.

Efekt wypychania w USA oszacowano na $12-13 \%$, co jest stosunkowo niskim wynikiem (Altonji i in., 1997, ss. 1121-1166; Cox i Jakubson, 1995, ss. 129-167). Zdaniem D. Coxa i in. (2004, ss. 2193-2219), przeprowadzanie badań o tej tematyce $w$ państwach rozwiniętych jest niecelowe, gdyż transfery prywatne zostały wypchnięte przez system zabezpieczenia społecznego już wiele dekad temu ${ }^{6}$. Zależność jest wciąż widoczna w państwach rozwijających się i to one powinny być przedmiotem badań $\mathrm{w}$ tym zakresie. W niektórych $z$ nich, aż połowa populacji dostaje transfery od członków swojej rodziny (World Bank, 2001, ss. 147-159). Ponadto, więzi i normy społeczne są w tych państwach $z$ reguły bardzo silne (co również przekonuje o trafności krytyki Coxa).

Efekt wypychania w Peru uchwycono tylko w niewielkim spadku prawdopodobieństwa jego otrzymania (o 6 p.p.), natomiast pochodna transferów względem dochodu przedtransferowego była dodatnia (Cox i in., 1997, ss. 57-80). H. Jung i in. (2016, ss. 455477), stwierdzają natomiast, że pobieranie emerytury w Korei Południowej zmniejsza prawdopodobieństwo otrzymania transferu aż o 40 p.p. 7 . W kolejnym badaniu, D. Cox $i$ in. (2004, ss. 2193-2219), szacują efekt wypychania $\mathrm{w}$ Filipinach na $40 \%$ dla ubogich gospodarstw domowych, podczas gdy dla bogatszych jest on statystycznie nieistotny. Wyniki na podobnym poziomie uzyskał E. Fan (2010, ss. 297-322), w odniesieniu do Tajwanu. . J. Gibson i in. (2004, ss. 1-19), zastosowali podobną metodologię do zbadania Indonezji, Wietnamu, Kambodży oraz Papui

Zdaniem R. Robertsa (1984, ss. 136-148), prywatna dobroczynność została wyparta już w latach 30 . XX wieku przez państwowe programy pomocy publicznej.

Autorzy badania wskazują, że wyniki mogą być niedokładne i przeszacowane. Wydaje się, że obok wielu powodów, jakie wymieniaja, może być to spowodowane zastosowaniem liniowych metod estymacji.

E. Fan (2010, ss. 297-322), w odróżnieniu od D. Coxa i in. (2004, ss. 2193-2219), stwierdza, że wprowadzenie powszechnych emerytur zwiększy społeczny dobrobyt poprzez zwiększenie zarówno konsumpcji młodego, jak i starszego pokolenia. 
Nowej Gwinei, jednak nie znaleźli statystycznie istotnego efektu wypychania?.

R. Jensen (2003, ss. 89-112), oszacował efekt wypychania w RPA na 25-30\%. Rezultat ten kontrastuje $z$ wnioskiem wypływającym z badania P. Maitra i R. Ray (2003, ss. 23-49), którzy przy użyciu nieliniowych metod regresji stwierdzają, że efekt wypychania w tym państwie wynosi tylko 9\% dla gospodarstw domowych znajdujących się poniżej linii ubóstwa, natomiast jest bliski zeru dla pozostałych. Takie rozbieżności mogą świadczyć o niewiarygodności oszacowań i nadmiernej wrażliwości wyników na zastosowaną metodologię.

Podsumowując, oszacowania efektu wypychania różnią się nie tylko między państwami, lecz także zastosowaną metodologią. W związku z tym, należy zachować ostrożność dokonując uogólnień ${ }^{10}$. Można natomiast stwierdzić, że efekt wypychania dotyczy $\mathrm{w}$ większym stopniu ubogich gospodarstw domowych.

Wydaje się natomiast, że nie powinno się na tej podstawie wyciągać wniosków o niesprawnym funkcjonowaniu systemu emerytalnego. Po pierwsze, zwiększanie konsumpcji osób w wieku poprodukcyjnym nie jest jedynym, ani głównym, celem tego systemu. Chodzi raczej o zapewnienie stabilnego dochodu przy minimalizacji obciążeń ponoszonych przez pokolenie pracujące (Góra, 2003, ss. 479-500), co nie jest tożsame z maksymalizacją konsumpcji starszego pokolenia. Emerytura gwarantuje stały i pewny dopływ środków pieniężnych, niezależnie od cyklu koniunkturalnego czy zdarzeń losowych (np. śmierć lub choroba w rodzinie). Czynniki te, mogą negatywnie wpłynąć na otrzymywanie transferów lub ich wysokość. Po drugie, zapewnienie emerytury $\mathrm{w}$ miejsce transferów, może eliminować potencjalne konflikty rodzinne, powstałe na tle majątkowym (Fan, 2010, ss. 297-322). Nie pozostaje to bez znaczenia dla dobrobytu

Za wyjątkiem wiejskich terenów Indonezji (24\% dla 20\% najbiedniejszych gospodarstw) oraz miejskich rejonów Kambodży ( $68 \%$ dla $5 \%$ najbiedniejszych gospodarstw).

${ }^{10}$ Stwierdzenie, zgodnie z Bankiem Światowym (World Bank, 2001, ss. 147-159), że efekt wypychania plasuje się na poziomie 21-91\%, wydaje się obciążone. społecznego. Ponadto, H. Jung i in. (2016, ss. 455-477), stwierdzają, że wprowadzenie emerytur zmniejszyło pomoc finansową dzieci dla rodziców i jednocześnie zwiększeniu uległa pomoc niefinansowa (odwiedziny, asysta, udzielanie informacji). Wydaje się oznaczać to zmniejszenie obciążeń, jakie ponoszone są przez młode pokolenia ${ }^{11}$, zatem wzrost stopnia realizacji celu systemu emerytalnego. Przytoczone argumenty świadczą o tym, $\dot{z}$ e istnienie efektu wypychania (nawet o dużej skali) nie powinno prowadzić do obaw co do nienależytego wypełniania funkcji systemu emerytalnego, a raczej być postrzeganym jako naturalna konsekwencja przejścia od systemu naturalnego do zinstytucjonalizowanego. W związku z tym, postulaty kompensacji najbiedniejszym gospodarstwom ubytku dochodów powstałego w wyniku wprowadzenia emerytur, nie są trafne $e^{12}$.

\section{Materiały i metody}

W związku z przedstawionymi w sekcji 2 . ułomnościami podejścia ekonometrycznego, zasadna będzie analiza problemu przy pomocy innych narzędzi takich, jak odpowiednio zmodyfikowany model nakładających się pokoleń. Zmiana polega na wprowadzeniu możliwości bezpośredniego transferowania majątku przez kohortę pracującą na rzecz starszej, co w sposób naturalny zmniejsza konsumpcję pierwszej grupy. Transfer może zostać dokonany $\mathrm{w}$ formie czysto pieniężnej, bądź w formie wysiłku (wsparcie niematerialne, np. usługi świadczone dla seniorów), stąd poniesiony koszt zmniejsza użyteczność młodszego pokolenia. Wysokość dokonywanych przesunięć majątkowych jest zdeterminowana rozwiązaniem zagadnienia optymalizacyjnego gospodarstw domowych. Specyfikacja modelu dana jest równaniami (1-15):

$$
N_{t}=\left(1+n_{t}\right) N_{t-1},
$$

Wymaga podkreślenia, że zmniejszenie to nie zawsze będzie widocznie w ujęciu majątkowym.

${ }^{2}$ Ubytek nie jest tu odpowiednim określeniem. Skoro efekt wypychania jest mniejszy od jedności, to gospodarstwa domowe, nawet te najbiedniejsze, nic nie tracą na wprowadzeniu emerytur, wręcz przeciwnie. 


$$
\begin{aligned}
& U_{t}=u\left(c_{1, t}, l_{1, t}\right)+\beta u\left(c_{2, t+1}\right), \\
& u(c, l)=\frac{1}{1-1 / \gamma} \cdot\left(c^{1-1 / \rho}+l^{1-1 / \rho}\right)^{\frac{1-1 / \gamma}{1-1 / \rho}} \\
& \operatorname{tr}_{1, t}=\left(1-l_{1, t}\right) \\
& w_{t}=s_{1, t+1}+p_{t} c_{1, t}+t r_{1, t}, \\
& R_{t+1} s_{1, t+1}+t r_{1, t}+p e n_{t+1}=p_{t+1} c_{2, t+1}, \\
& L_{t}=u\left(c_{1, t}, h_{1, t}\right)+\beta u\left(c_{2, t+1}\right)+ \\
& +\lambda_{1}\left(s_{1, t+1}+p_{t} c_{1, t}+t r_{1, t}-w_{t}\right)+ \\
& +\lambda_{2}\left(p_{t+1} c_{2, t+1}-\text { pen }_{t+1}-t r_{1, t}-R_{t+1} s_{1, t+1}\right) \text {, } \\
& Y_{t}=F\left(L_{t}, K_{t}\right) \text {, } \\
& y_{t}=\frac{Y_{t}}{L_{t}}=f\left(k_{t}\right) \text {, } \\
& r_{t}=f^{\prime}\left(k_{t}\right)-\delta \text {, } \\
& w_{t}=f\left(k_{t}\right)-f^{\prime}\left(k_{t}\right) k_{t}, \\
& Y_{t}=w_{t} L_{t}+\left(r_{t}+\delta\right) K_{t} \text {, } \\
& K_{t}=S_{t} \text {, } \\
& Y_{t}=C_{t}+\left(1+n_{t+1}\right) K_{t+1}-(1-\delta) K_{t} \text {, } \\
& I_{t}=\left(1+n_{t+1}\right) K_{t+1}-(1-\delta) K_{t},
\end{aligned}
$$

gdzie:

$N_{t}$ - liczba osób pokolenia urodzonego w okresie $t$;

$n_{t}$ - stopa przyrostu naturalnego w okresie $t$;

$u$ - użyteczność;

c - konsumpcja per capita danego pokolenia;

$l$-czas wolny;

$\gamma$ - międzyokresowa elastyczność substytucji konsumpcji;

$\rho$ - międzyokresowa elastyczność substytucji między konsumpcją a pracą;

$\operatorname{tr}_{1, t}$ - transfery pokolenia młodych dla pokolenia starych w okresie $t$; $w_{t}$ - płaca w okresie $t$;

$s_{i, t}$ - oszczędności i-tego pokolenia w okresie $t$;

pen - emerytura w okresie $t$;

$p_{t}$ - poziom cen w okresie $t$;

$\beta$ - stopa dyskontowa;

$R_{t}$ - stopa procentowa w okresie $t$;

$\lambda_{i}$ - i-ty mnożnik Lagrange'a;

$Y_{t}$ - produkcja w okresie $t$;

$K_{t}$ - kapitał w okresie $t$;

$L_{t}$ - podaż pracy w okresie $t$;

$y_{t}$ - produkcja per capita w okresie $t$;

$k_{t}$ - poziom kapitału per capita $\mathrm{w}$ okresie $t$;

$\delta$ - stopa deprecjacji;

$C_{t}$ - łączna konsumpcja w okresie $t$;

$I_{t}$ - inwestycje w okresie $t$.

Za pomocą programu Octave/Dynare przeprowadzono trzy symulacje: pierwszą dla gospodarki bez systemu emerytalnego, drugą - z systemem emerytalnym pay-as-you-go i trzecią - z kapitałowym systemem emerytalnym. W dwóch ostatnich założono jednostkowy efekt wypychania. Jeśli, mimo przyjęcia możliwie najgorszego scenariusza, wyniki gospodarcze, uzyskane na jego podstawie będą lepsze niż w modelu z systemem niezinstytucjonalizowanym, będzie to oznaczało ścisłą dominację tego pierwszego nad drugim, niezależnie od skali efektu wypychania.

\section{Wyniki}

Wyniki analizy zaprezentowano w tabeli 1 . Mimo że produkt per capita jest taki sam we wszystkich trzech scenariuszach, to łączna konsumpcja jest znacznie niższa w wariancie bez systemu zinstytucjonalizowanego (ubytek ten można określić pojęciem tzw. „jałowej straty"). W tym przypadku występują na tyle niekorzystne efekty, że pokolenia młodsze „zadłużają się"13 celem sfinansowania starszych. Obciążenie młodszej kohorty jest nieproporcjonalne $\mathrm{w}$ stosunku do ich możliwości.

${ }^{13}$ Ujemny znak przed wartością konsumpcji pokolenia młodszego może dziwić w kontekście braku rynku funduszy pożyczkowych. Wynika to z interpretacji pojęcia transferów. Warto przypomnieć, że mogą one być nie tylko przesunięciami dochodu, ale także „wysitkiem” zainwestowanym w świadczenie pomocy $z$ formie niematerialnej. 
Fakt ten odzwierciedlony jest $\mathrm{w}$ zauważalnie mniejszej wartości dobrobytu w gospodarce $z$ transferami międzypokoleniowymi niz w przypadku, gdy występują zinstytucjonalizowane systemy emerytalne.

Wnioski płynące $z$ analizy zmodyfikowanego modelu OLG potwierdzają konkluzje poczynione $\mathrm{w}$ sekcji 2 . Wprowadzenie zinstytucjonalizowanego systemu emerytalnego pozwala odciążyć młodsze pokolenie i uniezależnić dochód emerytów od zdarzeń losowych i cykli koniunkturalnych. Skutkuje to poprawieniem wyników gospodarczych, a także dobrobytu społecznego. Na tej podstawie można stwierdzić, że nawet przy istnieniu pełnego (jeden do jednego) efektu wypychania, korzyści ze wprowadzenia systemu emerytalnego byłyby dodatnie.

\section{Zakończenie}

$\mathrm{Na}$ podstawie przeprowadzonej analizy można stwierdzić, że nawet przy istnieniu efektu wypychania w skrajnej formie nie należy wyciągać wniosków o niesprawnym funkcjonowaniu systemu emerytalnego. Jego wprowadzenie wciąż będzie opłacalne. Postulaty kompensacji wywołanego ubytku osobom najuboższym, nie wydają się być trafne, gdyż ostatecznie koszty i tak ponieśliby pracujący.

Badanie konsekwencji efektu wypychania dla gospodarki jedynie $z$ perspektywy starszego pokolenia wydaje się być obarczone błędem, niezależnie od stopnia zaawansowania użytej metodologii. Warto mieć na uwadze, że to młodsze pokolenie wytwarza PKB, który jest następnie redystrybuowany między kohorty. Sama maksymalizacja konsumpcji seniorów, a zatem zbyt duże obciążenia nałożone na pracujących, może skutkować złą alokacją zasobów (przeznaczanie większości $z$ nich na pomoc starszym, zamiast na wytwarzanie produktu i własną konsumpcję) i w rezultacie spadkiem wolumenu, który pozostaje do podziału. $W$ ten sposób, paradoksalnie zmniejszona zostanie konsumpcja wszystkich kohort w dłuższym okresie.

\section{Bibliografia}

Altonji, J., Hayashi, F., i Kotlikoff, L. (1997). Parental altruism and inter vivos transfers: theory and evidence. Journal of Political Economy, 105(6). doi:10.1086/516388.

Barro, R. (1974). Are government bonds net wealth? Journal of Political Economy, 82(6). doi: $10.1086 / 260266$.

Becker, G. (1974). A theory of social interactions. Journal of Political Economy, 82(6). doi:10.1086/260265.

Bernheim, D., Shleifer, A., i Summers, L. (1985). The strategic bequest motive. Journal of Political Economy, 93(6). doi:10.1086/261351.

Cox, D. (1987). Motives for private income transfers. Journal of Political Economy, 95(3). doi: $10.1086 / 261470$.

Cox, D., Eser, Z. i Jimenez, E. (1997). Motives for private transfers over the life cycle: an analytical framework and evidence for Peru. Journal of Development Economics, 55(1). doi:10.1016/ s0304-3878(97)00056-4.

Cox, D., Hansen, B., i Jimenez, E. (2004). How responsive are private transfers to income? Evidence from a laissez faire economy. Journal of Public Economics, 88(9-10). doi:10.1016/ S0047-2727(03)00069-0.

Cox, D., i Jakubson, G. (1995). The connection between public transfers and private interfamily transfers. Journal of Public Economics, 57(1). doi:10.1016/0047-2727(94)01438-T.

Fan, E. (2010). Who benefits from public old age pensions? Evidence from a targeted program. Economic Development and Cultural Change, 58(2). doi:10.1086/647977.

Gibson, J., Le, T., Olivia, S., i Rozelle, S., (2004). Private transfers and the crowding out hypothesis: semiparametric and threshold regression. Evidence from four developing countries, Econometric Society 2004 Australasian Meetings, 112.

Góra, M. (2003). Inne spojrzenie na podstawowe zagadnienia ekonomii emerytalnej. Ekonomista, 4.

Jensen, R. (2003). Do private transfers 'displace' the benefits of public transfers? Evidence from South Africa. Journal of Public Economics, 88(1). doi:10.1016/s0047-2727(02)00085-3.

Jung, H., Pirog, M., i Lee, S. (2016). Do public pensions crowd out private transfers to the elderly? Evidence from South Korea. Journal of Pension Economics and Finance, 15(04). doi:10.1017/ s1474747214000493. 
Kaufman, D., i Lindauer, D. (1986). A model of income transfers for the urban poor. Journal of Development Economics, 22(2). doi:10.1016/0304-3878(86)90135-5.

Maitra, P., i Ray, R. (2003). The effect of transfers on household expenditure patterns and poverty in South Africa. Journal of Development Economics, 71(1). doi:10.1016/ s0304-3878(02)00132-3.

Roberts, R. (1984). A positive model of private charity and public transfers. Journal of Political Economy, 92(1). doi:10.1086/261212.

World Bank. (2001). World development report 2000/2001. doi:10.1596/0-1952-1129-4.
Informacje uzupetniające

Wkład autorski: autor zaakceptował ostateczną wersję artykułu.

Źródła finansowania: artykuł został w całości sfinansowany ze środków własnych autora.

Uwagi: wyniki badania były zaprezentowane na VIII Ogólnopolskiej Konferencji Naukowej z cyklu Problemy gospodarki światowej (Toruń, 20.04.2018). 
Aneks

Tabela 1 .

Wartości agregatów ekonomicznych per capita w trzech scenariuszach symulacji

\begin{tabular}{lccc}
\hline \multicolumn{2}{c}{ Agregat ekonomiczny } & Symulacja 1. & Symulacja 2. \\
\hline$y$ & 0,32 & 0,32 & 0,32 \\
$c$ & 0,26 & 0,44 & 0,62 \\
$c_{1}$ & $-1,30$ & 0,24 & 0,24 \\
$c_{2}$ & 1,60 & 0,20 & 0,38 \\
pen $t r$ & 0,09 & 0,09 & 0,29 \\
util & $-13,82$ & $-8,78$ & $-6,71$ \\
\hline
\end{tabular}

Uwagi:

$y$ - produkt per capita;

c- łączna konsumpcja per capita;

$c_{t}$ - konsumpcja pokolenia młodszego per capita;

$c_{2}$ - konsumpcja pokolenia starszego per capita;

pen/tr - wartość przysporzenia majątkowego dla pokolenia starszego (odpowiednio transfery, bądź emerytury);

util - użyteczność.

Źródło: Opracowanie własne.

The crowding out effect due to the introduction of the pension system

\begin{abstract}
Motivation: According to the World Bank, the introduction of pension system crowds out $20-91 \%$ of private transfers. The effect is particularly strong for the poorest households, which shall be main beneficiaries of this reform. According to the views presented in literature, this inclines to the questioning of the pension system itself.

Aim: The aim of the article is to answer the question, whether the introduction of obligatory pension system results in fact in crowding out of private transfers aimed to older people and, if the answer is positive, estimate the scale of the effect. It would allow to assess the effectiveness of the introduction of the pension system.

Materials and methods: A critical review of empirical studies, presented in the literature was conducted and then verified using a modified OLG (overlapping generations) model. The simulation was made in the Dynare/Octave program.

Results: It has been proved that even if the crowding out effect existed in its strongest form, it would not annihilate the sense of pension system. In the contrary, introduction of the latter would be profitable even in such a case - it would contribute to increase of consumption and social welfare.
\end{abstract}

Keywords: pension system; silver economy; OLG

JEL: J11; J14; J18 